\title{
Cultural Understanding In English Language Learning
}

\author{
Wuri Syaputri ${ }^{1}$ Fenny $_{\text {Theresia }}{ }^{2}$ Fatma Yuniarti $^{3}$ \\ Universitas Muhammadiyah Pringsewu ${ }^{1,3}$ Universitas Muhammadiyah Metro $^{2}$ \\ wurisyaputri@gmail.com ${ }^{1}$, fenny.theresia@yahoo.com ${ }^{2}$, \\ fatmayuniarti5@umpri.ac.id ${ }^{3}$
}

\begin{abstract}
Language and culture are two things that are interrelated in human life, especially in learning and langage teaching. The objective of this study is to dercribe the understanding of culture in learning English. This research belongs to qualitative research which applies libraries research to collect the data. The introduction of this culture is especially recommended for foreign language learning which places more emphasis on developing communication skills with the target language. The introduction of culture in learning English process can reduce the potential for misunderstandings to occur during the communication process.
\end{abstract}

Key words: culture, language, English, intercultural language

submit date: 20-02-2021 accept date: 11-03-2021 publish date: 13-03-2021

Correspondence author: Wuri Syaputri, Lampung, Indonesia. E-Mail: wurisyaputri@gmail.com

Doi: https://doi.org/10.36929/sigeh\%20elt.v1i1.354

\section{(c) (i) (2)}

Journal SIGEH licensed under a Creative Commons Attribution-ShareAlike 4.0 International License.

\section{INTRODUCTION}

Lestari, L. A. (2010). When we talk about language, culture will automatically enter into it too. Language is a communication tool that can facilitate a relationship between individuals in each country. English was the first language spoken in Britain and is now one of the most commonly spoken international languages in many countries. English is a foreign language in Indonesia which is certainly not used in everyday communication. Teaching English in Indonesia emphasizes mastery of four skills, namely listening, speaking, reading, and writing.

A student who can use good English grammar, vocabulary and pronunciation may not necessarily express his ideas smoothly and acceptably if the student does not have cultural knowledge when a sentence or utterance can be conveyed. For example, a student who is just learning introductory dialogue in English at school tries to practice in oral communication. When there is a foreign national woman near her house, she tries to get acquainted with "Hello, Miss. How old are you? " Grammatically, there is nothing wrong in the student's 
greeting sentence, but if greeting is assessed for its socio-cultural acceptability, it could be said that the greeting is unacceptable because in the English-speaking community asking for age to someone who is new, especially women is one of the things that less polite. This shows that how a sentence is true based on can be misinterpreted when used in an inappropriate context.

Abusyairi, K. (2013). Language and culture are two things that cannot be separated. Language is part of culture so that cultural understanding is very important to be applied in teaching foreign languages especially foreign languages, in this case, English. Culture plays an pilot role in establish the success of message delivery and the compose of smooth communication between the speaker and the interlocutor. So, in learning English it is not enough just to learn the aspects and components of the language, but learning cultural aspects is also very necessary. English teachers need to pay attention with cultural elements in their learning so that the students are able to use the language to communicate. For students, the English culture knowledge will help them to understand the situations they face when reading or listening to English texts.

\section{METHOD}

This research is a qualitative research. Observations were made by direct visits to local schools. The data collection technique is done through literature study. The results of data collection were analyzed and enriched through other written sources. To strengthen data analysis, further literature study was carried out to determine the process of understanding culture in learning English.

\section{RESULT AND DISCUSSION}

\section{A. Definition of Culture}

Culture has various meanings according to experts from various perspectives. Sowden (2007) defines culture as a set of traditional social, artistic, and thought patterns that have been historically associated with certain social groups or nations. According to Moran (2001), culture is a way of life for a group 
of people who are constantly changing, which consists of a set of practices related to a set of products, which are based on a set of perspectives, and occur in certain social contexts. This definition sees culture as formed from five interrelated dimensions, namely: products, practices, perspectives, society, and individuals. According to Moran (2001), these five dimensions are manifested in a model: some are visible and some are hidden, like a lump of ice in the sea, the top is clearly visible while the bottom is submerged in water. This definition also implies that culture is dynamic, related to the past but continues to move forward and change. This cultural dynamism is closely related to human nature which actively changes products, practices and the society in which the culture is located.

\section{B. Relationship between Culture and Language}

Language and culture are two things that are interrelated. According to Brown (1994), language is part of culture and vise versa. Learning a language cannot be separated from learning how language is used in daily life, especially how the language is influenced and also helps construct the culture of its native speakers.Brown (2001) states that the relationship between language and culture is very close, so that when talking about language, culture will automatically enter into it. Culture and language are two things that are interrelated. When learning a language, knowledge of the culture from which the language originates is required. For example, in English rice can be interpreted as paddy, rice, rice, and others. In the sentence I had fried rice for my breakfast. In the sentence rice means rice, and in the sentence, the farmer growa rice in the field, rice means rice. But in Javanese, rice has many meanings, ranging from rice, unhulled rice, the term for rice grains that have been separated from the stalks (straw), rice, the term for rice that has been separated from the husks, rice is rice that has been boiled (cooked), and others, depending on the context in which they exist. Another example is the word bring, in Indonesian the word has the meaning to bring, which can also be expanded depending on how to carry it, for example; mengunggi, namely carrying an object by placing it on the head; bear, namely carrying goods by hanging them 
on a stick that is placed on the shoulder; carrying, namely carrying something with your hands down and not holding it too tightly and others.

Another example that shows the relationship between culture and language is seen in the phenomenon of tense in English. In English, tense is used to describe activities that are carried out at different times. For example, I went to scool and I went to school. Both sentences have the meaning "I am going to school" but the time can already be known from the different verbs even without adding an adverb of the time in the sentence. Unlike the Indonesian language, there is no change in the verb, but it is necessary to add an adverb of the time.

Culture is indispensable in language learning because it prevents misunderstandings in communication. Language tends to be always involved in cultural aspects, for example language can be a means of cultural development; language becomes a mirror and a manifestation of the culture of the people; and someone can learn culture through his language. In other words, humans live and gain experiences from and with the help of language.

According to Nababan (1986), language is the key or the main door to deepen the culture of a society. Thus matters relating to life patterns, value systems, customs that live in the midst of a society can be understood and studied through his language.

\section{Understanding Culture in Learning English}

Developing cultural understanding in language learners is a challenging task for teachers when teaching languages. This is not only to have a sharp understanding of the concept but also to creatively assess the effective ways how these conceptual ideals can be applied in the classroom.McKay (2003) states that in the context of learning English as a foreign language, various cultures that apply in English-speaking communities need to be introduced to students so that they can be more sensitive to various cultural variations in English-speaking communities in order to develop intercultural communication skills. This can be done by integrating it into the material when learning and learning activities so that students can appreciate their own culture and at the same time can recognize their differences and similarities with other cultures. 
Zulianti, H., -Maximilian, A., \& Ajeng, G. D. (2016). The teaching of English cannot be separated from the cultural teaching of native English speakers. The most students the main opportunity to learn a foreign culture is when they learn the language. Foreign language learning is expected to include cultural learning as one of the elements that must be taught in class. Foreign language teachers are obliged to introduce cultural elements in the language learning they teach. Therefore, the teaching materials presented must be a replica of the situation in which the language is used in a natural cultural context.Afriani, Z. L. (2019). The relationship between culture and language is very close because they influence each other. In learning English, culture can be taught in an integrated manner with learning in four skills, namely, listening, speaking, reading, and writing. According to Brown (2001), the application of cultural learning can be done in several ways, namely:

1. Discuss cross-cultural differences between foreign cultures and students' native languages by emphasizing that no one culture is more than another;

2. Azizah, D. M., \& Surya, A. (2017). The cultural integration in English learning that is most often done by teachers is the cultivation of noble values. Include learning materials that illustrate the relationship between language and culture;

3. Teaches cultural connotations and sociolinguistic aspects of language learning; and 4. Padmawati, N. N., Nitiasih, P. K., \& Artini, L. P. (2009). Culture-based English learning is characterized by the inclusion of local culture at the material level. Choosing the right learning method in delivering material related to foreign cultures that is different from the original culture.

According to Liddicoat (2004), there is a main framework containing four activities related to culture, namely:

1. Studying and understanding a cultural practice,

2. Comparing cultural practices,

3. Exploring culture, and

4. Position oneself in the third place between two (or more) cultures. 
Liddicoat (2004) also mentions several possible strategies, including: explicit cultural teaching, integrating culture into four language skills, teaching culture from the beginning of language teaching, teaching bilingual, involving intercultural exploration, and helping learners to continue. learn.

Liddicoat, Papademetre, Scarino, \& Kohler (2003) proposed another strategy through five pedagogical principles which include:

1. Active construction, which implies the need for learners to seek and build their own knowledge of the target culture so that they are able to describe, analyze, and compare their culture with the target culture;

2. Making connections, which emphasizes the ability to connect and see intercultural linkages;

3. Social interaction, which is implemented through interactive discussions among learners;

4. Reflection, which is considered a key part that involves learners to respond and reflect on culture in a non-judgmental way; and

5. Responsibility, which implies the ability to build awareness of cultural differences and to respect people who have different cultural practices.

In the language learning process, it is very important to discuss crosscultural differences because this discussion will help students understand why a group of people perceives things differently when compared to other people's perspectives. This understanding can make students become broad-minded students who can understand cultural differences as something that also colors human life.

Moran (2001) states that cultural experiences on the involvement of learners in learning culture can be highlighted as the key to cultural learning. Language related to cultural learning is explained through four main functions, namely language to participate in culture, language to describe culture, language to interpret culture, and language to respond to the culture being studied.

The strategies presented above can be an alternative for language teachers to increase the cultural understanding of their learners. However, what needs to be 
kept in mind is that regardless of the strategies that teachers will use, they must ensure that each stage is meaningful and able to lead students to cultural understanding in language learning.

Learning vocabulary and language notes and practicing the four language skills is of course very important. But this can make students only learn a language as a whole if they are not introduced to the socio-cultural aspects of the language. Seeley (1993) states that this can be understood because knowledge of linguistic elements without knowledge of the cultural values prevailing in the language-user community is insufficient to be used as provisions so that students can communicate in a language acceptably.

\section{CONCLUSION}

Learning foreign languages in this case is that English does not always learn aspects of language such as grammar, pronunciation, vocabulary, spelling. However, learning a foreign language also involves cultural aspects inherent in the language. This cultural learning is necessary to avoid misunderstandings during the communication process between speakers and listeners. Communication can run smoothly if there is no mistake between the speaker and the listener. Obstacles in the process of communicating with a foreign language can of course always arise due to differences in language and culture. To unite these obstacles, a link is needed, namely communication between cultures. This intercultural communication can be started by introducing foreign language culture in the process of learning foreign languages to language learners.

\section{REFERENCE}

Abusyairi, K. (2013). Pembelajaran bahasa dengan pendekatan budaya. Dinamika Ilmu: Jurnal Pendidikan, 13(2).

Afriani, Z. L. (2019). Peran budaya dalam pemerolehan bahasa asing. Disastra: Jurnal Pendidikan Bahasa dan Sastra Indonesia, 1(2), 128-135. 
Azizah, D. M., \& Surya, A. (2017). Implementasi pembelajaran bahasa inggris sd berbasis budaya di yogyakarta. DWIJA CENDEKIA: Jurnal Riset Pedagogik, 1(1).

Bennet, J. M., \& Allen, W. (2003). Developing intetcultural competence in the language classroom. Greenwich: Information Age Publishing.

Brown, H. D. (1994). Principles of language learning and teaching. Englewood Cliffs, New Jersey: Prentice Hall Regents.

Brown, H. D. (2001). Teaching by principles: An interactive approach in language pedagogy. White Plain, New York: Addison Wesley Longman, Inc.

Lestari, L. A. (2010). Mengenalkan aspek budaya dalam pembelajaran bahasa Inggris. Lingua Didaktika, 3(2), 145-151.

Liddicoat, A. J., Papademetre, L., Scarino, A. \& Kohler, M. (2003). Report an intercultural language learning. Canberra: Australian Department of Education, Science and Traning.

Liddicoat, A.J. (2004). Intercultural language teaching: Principles for practice. The New Zaeland Language Teacher, vol.10.pp17-23.

McKay, S.L. (2003). The cultural basic of teaching English as an internasional languange. TESOL Matters 13 (4): 1-4.

Moran, P. R. (2001). Teaching culture: Perspective in practice. Boston, MA: Heinle and Heinle.

Nababan, P.W.J. (1986). Sosiolinguistik suatu pengantar. Jakarta: Gramedia.

Padmawati, N. N., Nitiasih, P. K., \& Artini, L. P. (2009). Model konseptual pembelajaran bahasa inggris berbasis budaya untuk sekolah dasar di bali. Jurnal Pendidikan dan Pengajaran, $42(3 \mathrm{Okt})$.

Seeley, H. N. 1993. Teaching culture. Lincolnwood, Ill.: National Textbook Company.

Sowden, C. (2007). Culture and the good teacher in the English language clasroom. ELT Journal 61 (4): 304-310.

Zulianti, H., Maximilian, A., \& Ajeng, G. D. (2016). Penyuluhan Tentang Pentingnya Pemahaman Budaya Dalam Mengajar Bahasa Inggris Bagi Guru-Guru Bahasa Inggris Di SMK PGRI 2 Bandar Lampung. Adiguna: Jurnal Pengabdian dan Pemberdayaan Masyarakat, 1(2), 1-5. 